\title{
Search for novel antipsychotic drugs: dopamine forever? István Gyertyán
}

\author{
Address: Department of Behavioural Pharmacology, Gedeon Richter, 1103 Budapest, Hungary \\ Email: István Gyertyán - i.gyertyan@richter.hu
}

from 15th Scientific Symposium of the Austrian Pharmacological Society (APHAR) Joint meeting with the Hungarian Society of Experimental and Clinical Pharmacology (MFT) and the Slovenian Pharmacological Society (SDF)

Graz, Austria. 19-21 November 2009

Published: 12 November 2009

BMC Pharmacology 2009, 9(Suppl 2):A52 doi:10.1 I86/I47I-22I0-9-S2-A52

This abstract is available from: http://www.biomedcentral.com/I47I-22I0/9/S2/A52

@ 2009 Gyertyán; licensee BioMed Central Ltd.

During the history of antipsychotic medications, the dopamine $\mathrm{D}_{2}$ receptor has been the crucial main target of drug action. Typical antipsychotics, which dominated the first 25 years of antipsychotic treatment as well as atypical antipsychotics, medications of the last three decades, all retained dopamine $\mathrm{D}_{2}$ receptor antagonism as the basic mode of action. Whether the superior side-effect profile (fewer extrapyramidal symptoms) of atypical antipsychotic agents is due to their serotonin $5-\mathrm{HT}_{2 \mathrm{~A}}$ receptor antagonist activity or to their looser binding to the dopamine $\mathrm{D}_{2}$ receptor is still a matter of debate. Brain imaging studies demonstrating a strong relationship between dopamine $\mathrm{D}_{2}$ receptor occupancy and clinical effects and side effects of antipsychotics gave fundamental support for a central role of dopamine $\mathrm{D}_{2}$ receptors in the pathology and therapy of schizophrenia. The clinical failure of alternative approaches lacking the $\mathrm{D}_{2}$ component, such as selective serotonin $5-\mathrm{HT}_{2 \mathrm{~A}}$ and dopamine $\mathrm{D}_{4}$ receptor antagonists further pointed at the indispensable role of $\mathrm{D}_{2}$ antagonism. The recently developed atypical antipsychotic agent, aripiprazole, while preserving the predominant $\mathrm{D}_{2}$ action, introduced a new pharmacological approach: dopamine $\mathrm{D}_{2}$ receptor partial agonism. An appropriate degree of partial agonism presumably results in effective blockade of overstimulated dopamine $\mathrm{D}_{2}$ receptors and improvement in psychotic symptoms, while it prevents the induction of extrapyramidal side effects or secondary negative symptoms by avoiding complete silencing of dopaminergic transmission. In recent years, the glutamatergic hypothesis for the pathology of the disease has gradually gained acceptance. Beside theoretical considerations, this concept was initially fuelled by some successful trials with the glutamate NMDA receptor coagonists glycine, $\mathrm{D}$-cycloserine and $\mathrm{D}$-serine on the negative symptoms of the disease. However, their efficacy was modest and these compounds were still applied as adjunct therapy to the standard $\mathrm{D}_{2}$ dopaminergic antipsychotics. The most recent and, perhaps, most promising "challenge" to the $\mathrm{D}_{2}$ centred therapy of schizophrenia has been the successful proof of concept trial with the selective metabotropic glutamatergic receptor $\mathrm{mGlu}_{2} /$ $\mathrm{mGlu}_{3}$ agonist prodrug compound, LY2140023. However, confirmation of the clinical efficacy of the compound is still awaited, and it has been raised that the compound may eventually affect - though indirectly dopaminergic mechanisms. It seems, despite several burial attempts and attractive alternative hypotheses and tremendous drug development efforts, the therapy of schizophrenia cannot - so far - detach itself from the dopaminergic system. 